\title{
Risk Assessment of Heavy Metal Pollution of Topsoil in the Proposed Land for UNIOSUN Teaching Hospital
}

\author{
Anifowose, A. J., Adewuyi, A. R., Babalola, O. O., Ajayi, M. T. and Adeleke, A. E.
}

\begin{abstract}
Heavy metals which are released to the soil are found to be deleterious to environment and biota. Such soil quality, particularly in residential proximities, must be assessed periodically. This study investigated nine (9) heavy metals $(\mathrm{Cu}, \mathrm{Pb}, \mathrm{Cd}, \mathrm{Fe}, \mathrm{Cr}, \mathrm{Zn}, \mathrm{As}, \mathrm{Mn}, \mathrm{Ni})$ in the surface soil of an agrarian land for Osun State University Teaching Hospital, Osogbo, with a view to establishing their potential threat. They were measured in twenty (20) composite soil samples of the site by inductively coupled plasma-optical emission spectrometry (ICP-OES). The results showed that the average concentrations of $\mathrm{Cu}(6.5 \mathrm{mg} / \mathrm{kg}), \mathrm{Pb}(5.4 \mathrm{mg} / \mathrm{kg}), \mathrm{Fe}(5831 \mathrm{mg} / \mathrm{kg}), \mathrm{Cr}$ (22 mg/kg), Zn (14.8 mg/kg), As (1.4 mg/kg), Mn (575 mg/kg), Ni (2.6 mg/kg) were within the permissible range and posed no ecological risk. However, Cd ranging $0.1-1.3 \mathrm{mg} / \mathrm{kg}$ (average, 0.6 $\mathrm{mg} / \mathrm{kg}$ ) moderately posed ecological risk due to its positive geo-accumulation index and constituted $86.5 \%$ of risk index of all the metals. Applications of agrochemicals, fertilizers in the previous agricultural activities could be the primary sources of the elevated concentration of $\mathrm{Cd}$ measured in the soil. The overall pollution assessment of the surface soil indicated moderate pollution of the site soil by the heavy metals.
\end{abstract}

Keywords: heavy metals; pollution indices; geo-contamination; geo-accumulation index; anthropogenic activities

\section{Introduction}

The detrimental impacts of heavy metals on the health of flora and fauna cannot be overemphasized [1]. Although this group of environmental pollutants naturally constitute the earth's crust, it forms deposits in the soil through various human activities. Chiefly among these are the application of agrochemicals such as pesticides, fertilizers [2], [3] and industrial activities which include: metalfinishing, paint production, chemical and battery manufacturing, leather tanning, mining activities, foundries and smelters [4]-[6] improper disposal of wastes [7]. Traffic emissions and other human activities like urban

\footnotetext{
Anifowose, A. J., Adewuyi, A. R., Babalola, O. O. and Ajayi, M. T. (Department of Pure and Applied Chemistry, Faculty of Basic and Applied Sciences, Osun State University, Osogbo, Nigeria)

Adeleke, A. E (Department of Basic Sciences (Chemistry Unit), Faculty of Science, Adeleke University, P.M.B. 250, Ede, Nigeria)

Corresponding author: adebanjo.anifowose@uniosun.edu.ng Telephone Number: +234-906-621-5382
}

and municipal wastewater sludge depositions are other notable ways by which heavy metals are released to the environment. Domestic activities can also contribute to sources and spread of heavy metals. Mechanical sources of heavy metals include combustion of fuel $(\mathrm{Pb})$, lubricant oil, brake and tire wears $(\mathrm{Cu}$ and $\mathrm{Pb})$.

Heavy metals are persistent in the environment due to their inability to undergo microbial or chemical degradation unlike organic contaminants which are oxidized to $\mathrm{CO}_{2}$ [8]; however, changes in their chemical forms (speciation) and bioavailability are possible [9]. Soil contamination by heavy metals, most oftentimes, leads to groundwater contamination and may pose risks and hazards to humans and the ecosystem. Significant classes of human diseases suspected to result from exposure to environmental chemicals are cancers, birth and immune system defects, mental retardation (low IQs), immunotoxicity, altered sex hormone balance, altered metabolism, low fertility, behavioural abnormalities, and explicit organ 
dysfunctions [10]-[12]. In recent times, it has broadly been acknowledged that environmental chemicals do exhibit their harmfulness not only as single entities but also as mixtures [13]. Other negative impacts include a reduction in land usability for agricultural production causing food insecurity, and land tenure problem [14]. To protect human health from the adverse effects of heavy metals, international organizations set standards using individual metals. These safety standards are set with the assumption that there is a minimal interaction between metal or chemical species and, even if there are interactions, the degree will not exceed safety factors applied [15].

In 2018, Osun State University, Osogbo (Nigeria), cleared the newly acquired site for its Teaching Hospital, called Osun State University Teaching Hospital (hereafter referred to as OSUNTH). For some years, the land has been in use for farming activities (yam, maize and cassava cultivation) during which various agrochemicals have been applied. Several domestic and municipal wastes have been dumped on the land over the years. Hence, it is plausible that the site soil has been severely impacted. Literature indicates some studies that have been carried out to evaluate heavy metals pollution on Osogbo soils [16]-[18] were carried out to evaluate their pollution by heavy metals. However, no such study has been extended to the soil of the proposed site which necessitates this study. Being a prospective public health facility, background concentrations of heavy metals in the site soil are needed for continuous assessment of the eventual impacts of the hospital activities. This is in addition to the fact that the groundwater quality of the Teaching Hospital will be influenced by the soil heavy metals.

\section{Materials and Method}

\section{A Study Area}

The study area is about $130,146 \mathrm{~m}^{2}$ and located in the peri-urban area of Osogbo (Figure 1). It is located at $1.5 \mathrm{~km}$ from Osun State University (Osogbo campus).

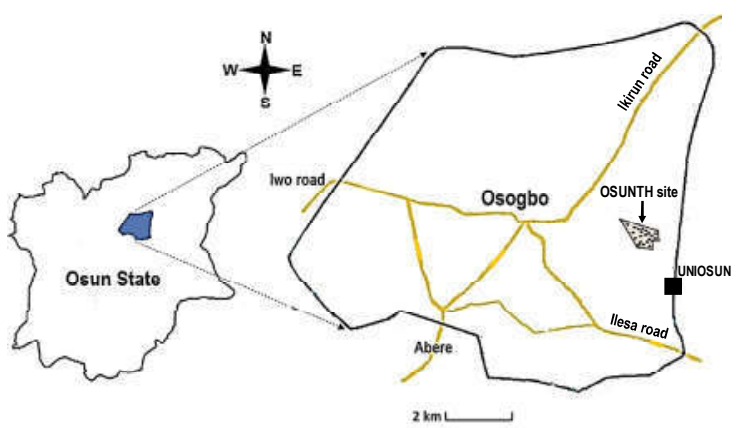

Figure 1: Map showing soil sampling at Osun State University Teaching Hospital (OSUNTH), Osogbo

The southern boundary of the site is about 600 $\mathrm{m}$ away from Osogbo-Ibokun major road. High-tension electricity lines (132 and $330 \mathrm{kV}$ ) bordered the site at the West. The Osun State Broadcasting Corporation (OSBC) is $600 \mathrm{~m}$ distant from the southwestern part of the site. Iludun Community is about $500 \mathrm{~m}$ away from the northwestern border of the site. The immediate neighbouring environment of the site is undeveloped with some maize, cassava and yam farms. The site was used for farming in the past decades. To the Northeast is a small portion of the site previously used as a dumpsite.

\section{B Soil Sampling and Analysis of Heavy Metals}

Surface soil samples $(0-10 \mathrm{~cm}$ depth) covering the entire site, were taken at various points for the study. The soil samples were obtained with a hand auger (Darham Geo Slope Indicator Narodown). Twenty (20) composite samples were taken; a composite soil sample is a thorough mixture of ten soil samples randomly taken within about $6,500 \mathrm{~m}^{2}$ area. Foreign objects such as stones, glass, plant debris, 
wood, and other residues, were removed from the sample before mixing thoroughly. The samples were kept in airtight bags (zip lock) labelled and transported to the laboratory. The samples were air-dried at ambient temperature in the laboratory and sieved to $425 \mu \mathrm{m}$ particle size using a standard laboratory sieve. A map showing the sampling locations is shown in Figure 1.

One gram $(1 \mathrm{~g})$ of the prepared soil sample was digested with concentrated nitric acid till the clear solution was observed. After cooling, the mixture was filtered. The filtrate was diluted to $100 \mathrm{ml}$ with distilled water and subsequently analyzed for $\mathrm{Fe}, \mathrm{Zn}, \mathrm{Mn}, \mathrm{Cu}, \mathrm{Cd}, \mathrm{Cr}$, As, Ni and $\mathrm{Pb}$ using an inductively coupled plasmaoptical emission spectrometer (ICP-OES; Agilent 720). Quality control of the analysis was ensured by running a blank and standard solution of heavy metals (AccuStandard Inc, USA). Analyses were done in triplicate to ensure the precision of the analytical procedure and instrument used.

\section{Assessment of the Soil Pollution Level and Ecological Risk}

As established in literature, various pollution indices which include geo-accumulation index $\left(\mathrm{I}_{\text {geo }}\right)$ and ecological risk assessment $\left(\mathrm{E}_{\mathrm{r}}\right)$ were used to assess the pollution degree of the soil. Geo-accumulation index shown in equation (1) was employed to assess the individual metal contamination [19]-[23].

$\mathrm{I}_{\text {geo }}=\log _{2}\left(\frac{c_{\mathrm{nl}}}{1,5_{\mathrm{n}}}\right)$

where $C_{n}$ and $B_{n}$ are the soil concentration (measured)and geochemical background concentration (reference value) of metal " $n$ ", respectively. To lessen the effect of likely variations in the background values due to lithogenic variations in the soil, the factor " 1.5 " was introduced [19], [20], [23]. In this study, the mean concentrations $(\mathrm{Cr}=135, \mathrm{Ni}=20, \mathrm{Cu}=$
26, $\mathrm{As}=1.5, \mathrm{Cd}=0.2, \mathrm{Zn}=66$ and $\mathrm{Pb}=15)$ of metals in the earth's crust [24] were used as geochemical background concentration [25].

The ecological risk assessment of the individual heavy metal was done using equation 2 :

$$
\mathrm{E}_{\mathrm{r}}=\mathrm{T}_{\mathrm{i}} \times\left(\frac{\mathrm{c}_{\mathrm{nl}}}{\mathbf{B}_{\mathrm{n}}}\right)
$$

Where $E_{r}$ is the ecological risk factor, $T_{i}$ is the toxic response factor of the individual metal $(\mathrm{Zn}=1, \mathrm{Cr}=2, \mathrm{Ni}=\mathrm{Cu}=\mathrm{Pb}=5, \mathrm{As}=10$ and $\mathrm{Cd}=30)$ [26], [27].

The potential ecological Risk Index (RI) of all the measured metals in the soil, calculated as the sum of environmental risk factors of all the metals was determined according to equation 3 [26], [28]:

$$
\mathrm{RI}=\Sigma \mathrm{E}_{\mathrm{r}}
$$

Table 1 categorizes the soil pollution levels based on $\mathrm{I}_{\text {geo, }}$ Er and RI calculated results.

\section{Results and Discussion}

\section{A Concentrations of Heavy Metals in OSUNTH Soil}

The concentrations of the measured heavy metals in the topsoil of the proposed OSUNTH site are presented in Table 2. Concentrations of the heavy metals varied widely in the site soil, except for $\mathrm{Cu}, \mathrm{Cr}$ and As. This indirectly signifies non-homogeneity in the composition of the soil sample considering the land expanse. Being among the most abundant elements in the soil, $\mathrm{Fe}$ and $\mathrm{Mn}$ have the highest concentrations in this study ranging 2230-9423 (average, $5831 \mathrm{mg}$ ) and 145-932 $\mathrm{mg} / \mathrm{kg}$ (average, $575 \mathrm{mg} / \mathrm{kg}$ ), respectively. The average concentrations $(\mathrm{mg} / \mathrm{kg})$ of the toxic metals increased in order of: $\mathrm{Cr}(22)>\mathrm{Zn}(14.8)>\mathrm{Cu}(6.5)>\mathrm{Pb}(5.4)>\mathrm{Ni}(2.6)>\mathrm{A}$ $\mathrm{s}(1.4)>\mathrm{Cd}(0.6)$. 
Table 1: Soil pollution categories based on $\mathrm{I}_{\text {geo, }}$ Er and RI values

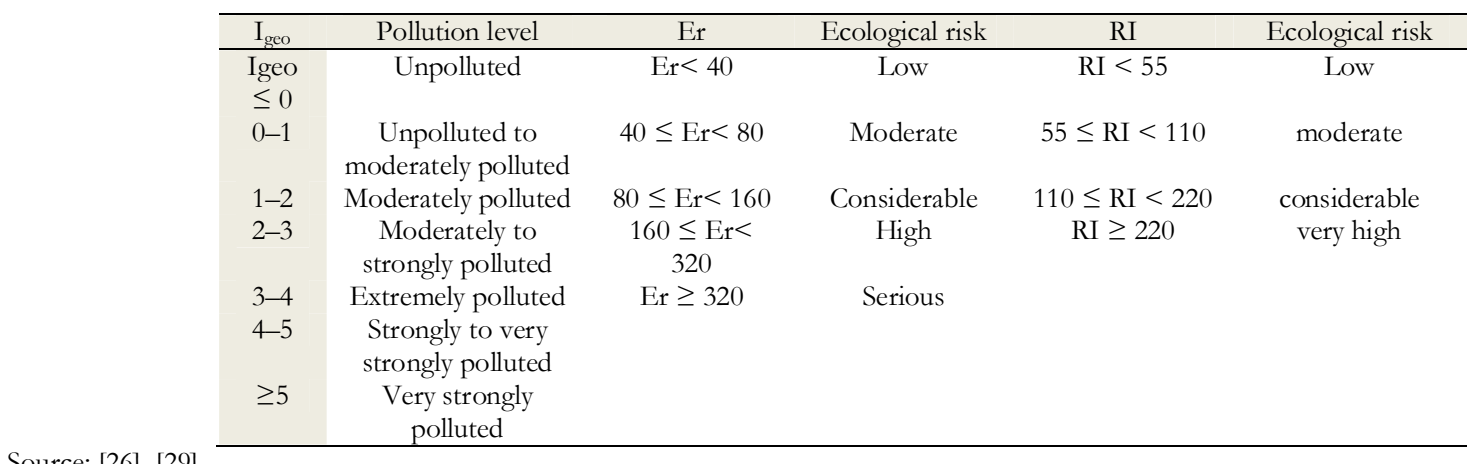

Source: [26]-[29].

Table 2: Comparison of the heavy metals in OSUNTH soil with other studies

\begin{tabular}{|c|c|c|c|c|c|c|c|c|c|c|}
\hline \multirow{2}{*}{$\begin{array}{l}\text { Study } \\
\text { location }\end{array}$} & \multicolumn{9}{|c|}{ Heavy metals (mg/kg) } & \multirow[t]{2}{*}{ Reference } \\
\hline & $\mathrm{Cu}$ & $\mathbf{P b}$ & $\mathrm{Cd}$ & $\mathrm{Fe}^{*}$ & $\mathrm{Cr}$ & $\mathrm{Zn}$ & As & $\mathbf{M n}^{*}$ & $\mathrm{Ni}$ & \\
\hline $\begin{array}{l}\text { Osogbo, } \\
\text { Nigeria }\end{array}$ & $\begin{array}{l}6.5 \pm 0.6 \\
(4.8-7.7)\end{array}$ & $\begin{array}{l}5.4 \pm 1.1 \\
(1.3- \\
7.5)\end{array}$ & $\begin{array}{l}0.6 \pm 0.3 \\
(0.1- \\
1.3)\end{array}$ & $\begin{array}{l}0.58 \pm 0 . \\
2 \\
(0.2- \\
0.9)\end{array}$ & $\begin{array}{l}22 \pm 2.6 \\
(17-28)\end{array}$ & $\begin{array}{l}14.8 \pm 4.6 \\
(7.6-26)\end{array}$ & $\begin{array}{l}1.4 \pm 0.3 \\
(0.8-1.9)\end{array}$ & $\begin{array}{l}0.06 \pm 0.0 \\
1 \\
(0.01- \\
0.1)\end{array}$ & $\begin{array}{l}2.6 \pm 0.8 \\
(0.6-4.5)\end{array}$ & This study \\
\hline $\begin{array}{l}\text { Ibadan, } \\
\text { Nigeria }^{a}\end{array}$ & $\begin{array}{l}46.8 \pm 44 . \\
1\end{array}$ & $\begin{array}{l}95.1 \pm 14 \\
.6\end{array}$ & $\begin{array}{l}8.4 \pm 19 . \\
8\end{array}$ & - & $\begin{array}{l}64.4 \pm 50 . \\
5\end{array}$ & $228.6 \pm 366$ & $3.9 \pm 4.44$ & $\begin{array}{l}0.11 \pm 0.0 \\
5\end{array}$ & $\begin{array}{l}20.2 \pm 14 . \\
6\end{array}$ & [35] \\
\hline $\begin{array}{l}\text { Osogbo, } \\
\text { Nigeriaa }^{a}\end{array}$ & $110 \pm 90$ & $137 \pm 64$ & - & - & $3.6 \pm 2.46$ & $1133 \pm 897$ & - & - & $\begin{array}{l}26.3 \pm 51 . \\
1\end{array}$ & [16] \\
\hline $\begin{array}{l}\text { Cambridge } \\
\text { City }\end{array}$ & $2-250$ & $2-300$ & $0.01-2.0$ & - & $5-1500$ & $1-900$ & $0.1-40$ & - & $2-750$ & [36] \\
\hline $\begin{array}{l}\text { Brisbane, } \\
\text { Australia }\end{array}$ & $20-110$ & $25-126$ & $0.6-0.9$ & $5.1-7.7$ & $82-332$ & - & - & $0.03-0.1$ & $20-34$ & {$[37]$} \\
\hline Earth's shale ${ }^{a}$ & 45 & 20 & 0.3 & 4.7 & 90 & 95 & 13 & 0.08 & 68 & [30] \\
\hline $\mathrm{UCC}^{\mathrm{a}}$ & 14.3 & 17 & 0.1 & 3.09 & 35 & 52 & - & 0.05 & 18.6 & [31] \\
\hline WHO & 36 & 85 & 0.8 & - & 100 & 50 & - & - & 35 & [38] \\
\hline $\begin{array}{l}\text { Worldwide } \\
\text { soils }^{\mathrm{a}}\end{array}$ & 20 & $15-28$ & 0.5 & 3.5 & 54 & 63 & $\leq 30$ & $\leq 0.9$ & $19-22$ & [24] \\
\hline
\end{tabular}

Table 3: Geo accumulation index $\left(\mathrm{I}_{\text {geo }}\right)$ and ecological risk $\left(\mathrm{E}_{\mathbf{r}}\right)$ of heavy metals in OSUNTH Soil

\begin{tabular}{|c|c|c|c|c|c|c|c|c|c|c|c|c|c|c|c|}
\hline & \multicolumn{2}{|l|}{$\mathrm{Cu}$} & \multicolumn{2}{|l|}{$\mathbf{P b}$} & \multicolumn{2}{|l|}{$\mathrm{Cd}$} & \multicolumn{2}{|l|}{$\mathrm{Cr}$} & \multicolumn{2}{|l|}{$\mathrm{Zn}$} & \multicolumn{2}{|l|}{ As } & \multicolumn{2}{|l|}{$\mathbf{N i}$} & \multirow[t]{2}{*}{$\mathbf{R I}$} \\
\hline & $\mathrm{Er}$ & $\mathbf{I}_{\text {geo }}$ & Er & $\mathbf{I}_{\text {geo }}$ & $\mathrm{Er}$ & $\mathbf{I}_{\text {geo }}$ & $\mathrm{Er}$ & $\mathbf{I}_{\text {geo }}$ & $\mathrm{Er}$ & $\mathbf{I}_{\text {geo }}$ & Er & $\mathbf{I}_{\text {geo }}$ & $\mathrm{Er}$ & $\mathbf{I}_{\text {geo }}$ & \\
\hline Average & 1.3 & -2.6 & 1.8 & -2.1 & 90 & 1.0 & 0.3 & -3.1 & 0.2 & -2.7 & 9.3 & -0.7 & 0.7 & -3.5 & 104 \\
\hline Minimun & 0.9 & -3.0 & 0.4 & -4.1 & 15 & -1.6 & 0.3 & -3.5 & 0.1 & -3.6 & 5.3 & -1.5 & 0.2 & -5.6 & 22 \\
\hline maximum & 1.5 & -2.3 & 2.5 & -1.6 & 195 & 2.1 & 0.4 & -2.8 & 0.4 & -1.9 & 12.7 & -0.2 & 1.1 & -2.7 & 214 \\
\hline
\end{tabular}

The average concentrations of heavy metals are compared with other studies and acceptable standards (Table 2). Except for cadmium, the measured concentrations of the heavy metals were not higher than permissible metal concentrations (standards) in soil [24], [30], [31]. The elevated cadmium concentration $(0.1-$ $1.3 \mathrm{mg} / \mathrm{kg})$ ) in site soil could be traced to the previous applications of phosphate fertilizers, batteries, refuse incineration, coal and wood combustion [32]. Pesticides and insecticides application, especially during the previous agricultural activities, would also increase the natural Cd concentration in the site soil [33].

It is well known that metals are natural components of soil. However, there were diverse anthropogenic activities that could contribute to other metals measured in this study. Agricultural activities such as application 
of phosphate fertilizers would introduce $\mathrm{Cu}, \mathrm{Ni}$, $\mathrm{Pb}$ and $\mathrm{Zn}$ [33], while coal and wood combustion could release $\mathrm{Zn}$. Application of agrochemicals such as insecticides and pesticides are potentials sources of $\mathrm{Cu}, \mathrm{Pb}$ and $\mathrm{Zn}$; fungicides being a good source of $\mathrm{Cu}$ [33]. Anthropogenic refuse incineration, dumping of metal scraps and used batteries are capable of discharging toxic heavy metals like $\mathrm{Pb}, \mathrm{Cd}, \mathrm{Zn}$ and $\mathrm{Cd}$ into the soil. Spillage of automobile oils such as lubricating oil, transmission fluid, and grease is a potential cause of heavy metals accumulation in soil [33]. Though could be insignificant, the release of automobile exhaust from the nearby Osogbo-Ibokun road on the site would have impacted on the natural levels of the soil heavy metals. A recent study [32] confirmed that some of the soil polycyclic aromatic hydrocarbons (PAHs) originated from the automobile exhaust from the road.

\section{B Assessment of Pollution Risk of the Heavy Metals in OSUNTH Soil}

The results of the three pollution indices used in assessing the soil pollution level and potential ecological risk are presented in Table 3. Only cadmium was found to possibly pose a pollution threat among the heavy metals measured.

This is because, the calculated $I_{\text {geo }}$ values of all the other heavy metals (except Cd) were less than zero; $I_{\text {geo }}$ for Cd ranged -1.6-2.1 (average, 1.0). Similarly, the ecological risk factor of the individual metal was less than 40 , indicating low potential ecological risk by each metal. However, cadmium with an average ecological risk factor of 90 (range, 15-195) poses a considerable ecological risk and constitutes $86.5 \%$ of the risk index (RI). RI would characterize the sensitivity of the local ecosystem to the toxic metals and represents the ecological risk resulting from the overall contamination [39]. The overall potential ecological risk (RI) of the measured metals in the soil was calculated as the sum of all the ecological risk factors of the measured metals (Table 3). The RI ranged from 22 to 214 (average, 104) and considered moderate pollution of the soil.

\section{Conclusion}

This study shows that previous agricultural and anthropogenic activities contributed to an environmentally tolerable amount of heavy metals to the site soil.

Summarily, the surface soil composition of the proposed site for the Osun State University Teaching Hospital was relatively unpolluted by the heavy metals, though cadmium could pose a potential threat in the future if preventive/prohibitive measures are not taken. The low pollution level, notwithstanding previous agricultural/anthropogenic activities, portends good development for the site as clean soil environment is required for such public institution. This is in addition to the fact that underground water (borehole) will be a major water source for the hospital. The health safety of the patients and workers in the hospital, as well as the sustainability of farming activities around the site, will indirectly depend on the soil quality at this site. Continuous monitoring and periodic evaluation of the cadmium level in the Teaching Hospital soil are important. Thus, the data in this study will form background concentrations of the heavy metals in the subsequent, related studies.

\section{Competing Interest}

The authors declare no competing financial interest or conflict of interest.

\section{References}

[1] Skoog, D. A., West, D. M., Holler, F. J. and Crouch, S. R. Fundamentals of analytical chemistry, Nelson Education, 2013.

[2] Al-Khashman, O. A. "Heavy metal distribution in dust, street dust and soils from the work place in Karak Industrial Estate, Jordan", Atmos. Environ., vol. 38, no. 39, 2004, pp. 6803- 
6812.

[3] Nouri, J., Mahvi, A. H., Jahed, G. R. and Babaei, A. A. "Regional distribution pattern of groundwater heavy metals resulting from agricultural activities", Environ. Geol., vol. 55, no. 6, 2008, pp. 1337-1343.

[4] Akopyan, K., Petrosyan, V., Grigoryan, R. and Melkomian, D. M. "Assessment of residential soil contamination with arsenic and lead in mining and smelting towns of northern Armenia", J. Geochemical Explor., vol. 184, 2018, pp. 97-109.

[5] Lu, H. P., Li, Z. A., Gascó, G., Méndez, A., Shen, Y. and Paz-Ferreiro, J. "Use of magnetic biochars for the immobilization of heavy metals in a multi-contaminated soil", Sci. Total Environ., vol. 622, 2018, pp. 892-899.

[6] Liu, K., Li, C., Tang, S., Shang, G., Yu, F. and $\mathrm{Li}, \mathrm{Y}$. "Heavy metal concentration, potential ecological risk assessment and enzyme activity in soils affected by a lead-zinc tailing spill in Guangxi, China", Chemosphere, 2020, p. 126415.

[7] Abdulrashid, L., Yaro, A. and Isah, A. "Heavy Metals Contamination in Urban Soils of Nigerian: A Review", Int. J. Innov. Biosci. Res. 51, vol. 12, 2017.

[8] Kirpichtchikova, T. A., Manceau, A., Spadini, L., Panfili, F., Marcus, M. A. and Jacquet, T. "Speciation and solubility of heavy metals in contaminated soil using X-ray microfluorescence, EXAFS spectroscopy, chemical extraction, and thermodynamic modeling", Geochim. Cosmochim. Acta, vol. 70, no. 9, 2006, pp. 2163-2190.

[9] Maslin, P. and Maier, R. M. "Rhamnolipidenhanced mineralization of phenanthrene in organic-metal co-contaminated soils", Bioremediat. J., vol. 4, no. 4, 2000, pp. 295-308.

[10] Carpenter, D. O., Arcaro, K. and Spink, D. C. "Understanding the human health effects of chemical mixtures", Environ. Health Perspect., vol. 110, no. suppl 1, 2002, pp. 25-42.

[11] Pimentel, D., Cooperstein, S., Randell, H., Filiberto, D., Sorrentino, S., Kaye, B., Nicklin, C., Yagi, J., Brian, J. O'Hern, J., Habas, A. and Weinstein, C. "Ecology of increasing diseases: population growth and environmental degradation", Hum. Ecol., vol. 35, no. 6, 2007, pp. 653-668.

[12] Prüss-Ustün, A., Vickers, C., Haefliger, P. and Bertollini, R. "Knowns and unknowns on burden of disease due to chemicals: a systematic review", Environ. Heal., vol. 10, no. 1, 2011, p. 9.

[13] Wang, G. and Fowler, B. A. "Roles of biomarkers in evaluating interactions among mixtures of lead, cadmium and arsenic", Toxicol. Appl. Pharmacol., vol. 233, no. 1, 2008, pp. 92-99.

[14] Ling, W., Shen, Q., Gao, Y., Gu, X. and Yang, Z. "Use of bentonite to control the release of copper from contaminated soils", Soil Res., vol. 45, no. 8, 2008, pp. 618-623.

[15] Jadhav, S. H., Sarkar, S. N., Ram, G. C. and Tripathi, H. C. "Immunosuppressive effect of subchronic exposure to a mixture of eight heavy metals, found as groundwater contaminants in different areas of India, through drinking water in male rats", Arch. Environ. Contam. Toxicol., vol. 53, no. 3, 2007, pp. $450-458$.

[16] Abidemi, O. O. and Onwordi, C. T. "Environmental fate of heavy metals in soil of IdoOsun waste dump site, Osogbo, Osun, Nigeria", Am. J. Environ. Prot., vol. 1, 2015, pp. 1-4.

[17] Fakayode, S. O. and Olu-Owolabi, B. I. "Heavy metal contamination of roadside topsoil in Osogbo, Nigeria: its relationship to traffic density and proximity to highways", Environ. Geol., vol. 44, no. 2 , 2003, pp. 150-157.

[18] Alabi, O. O., Sedara, S. O. and Awowole, S. Y. "Assessment of concentrations of heavy metals in soils around ESPRO asphalt production and quarry site, Wasinmi, Osun State Southwest Nigeria," J. Geogr. Environ. Earth Sci. Interanational, vol. 22, no. 3, 2019, pp. 1-10, doi: https://doi.org/10.9734/jgeesi/2019/v22i330148.

[19] Muller, G. "Index of geoaccumulation in sediments of the Rhine River," GeoJournal, vol. 2, 1969, pp. 108-118.

[20] Adimalla, N. "Heavy metals pollution assessment and its associated human health risk evaluation of urban soils from Indian cities: a review", Environ. Geochem. Health, vol. 42, no. 1, 2020, pp. 173-190, doi: 10.1007/s10653-019-003244.

[21] Hou, S., Zheng, N., Tang, L., Ji, X., Li, Y. and Hua, X. "Pollution characteristics, sources, and health risk assessment of human exposure to $\mathrm{Cu}$, $\mathrm{Zn}, \mathrm{Cd}$ and $\mathrm{Pb}$ pollution in urban street dust across China between 2009 and 2018," Environ. Int., vol. 
128, 2019, pp. 430-437.

[22] Sulaiman, M. B., Santuraki, A. H. and Babayo, A. U. "Ecological risk assessment of some heavy metals in roadside soils at traffic circles in Gombe, northern Nigeria", J. Appl. Sci. Environ. Manag., vol. 22, no. 6, 2018, p. 999, doi: 10.4314/jasem.v22i6.26.

[23] Sulaiman, M. B., Salawu, K. and Barambu, A. U. "Assessment of Concentrations and Ecological Risk of Heavy Metals at Resident and Remediated Soils of Uncontrolled Mining Site at Dareta Village, Zamfara, Nigeria", J. Appl. Sci. Environ. Manag., vol. 23, no. 1, 2019, pp. 187-193.

[24] Kabata-Pendias, A. and Mukherjee, A. B. Trace elements from soil to human, Springer Science \& Business Media, 2007.

[25] Khademi, H., Gabarrón, M., Abbaspour, A., Martínez-Martínez, S., Faz, A. and Acosta, J. A. Environmental impact assessment of industrial activities on beavy metals distribution in street dust and soil, vol. 217, Elsevier Ltd, 2019.

[26] Hakanson, L. "An ecological risk index for aquatic pollution control. A sedimentological approach", Water Res., vol. 14, no. 8, 1980, pp. 9751001.

[27] Cui, Song, Zhang, F., Hu, P., Hough, R., Fu, Q., Zhang, Z., An, L., Li, Y-F., Li, K., Liu, D. and Chen, P. "Heavy metals in sediment from the urban and rural rivers in Harbin City, Northeast China," Int. J. Environ. Res. Public Health, vol. 16, no. 22, 2019, p. 4313.

[28] Kumar, V., Sharma, A., Minakshi, Bhardwaj, R. and Thukral, A. K. "Temporal distribution, source apportionment, and pollution assessment of metals in the sediments of Beas river, India", Hum. Ecol. Risk Assess., vol. 24, no. 8, pp. 2162-2181, 2018, doi: 10.1080/10807039.2018.1440529.

[29] Mehr, M. R., Keshavarzi, B., Moore, F., Sacchi, E., Lahijanzadeh, A. R., Eydivand, S., Jaafarzadeh, N., Naserian, S., Setti, M. and Rostami, S. "Contamination level and human health hazard assessment of heavy metals and polycyclic aromatic hydrocarbons (PAHs) in street dust deposited in
Mahshahr, southwest of Iran", Hum. Ecol. Risk Assess. An Int. J., vol. 22, no. 8, 2016, pp. 17261748.

[30] Turekian, K. K. and Wedepohl, K. H. "Distribution of the elements in some major units of the earth's crust", Geol. Soc. Am. Bull., vol. 72, no. 2, 1961, pp. 175-192.

[31] Wedepohl, K. H. "The composition of the continental crust," Geochim. Cosmochim. Acta, vol. 59, no. 7, 1995, pp. 1217-1232.

[32] Anifowose, A. J., Ogundola, A. O., Babalola, B. M. and Awojide, S. H. "Measurement, Source-Profiling and Potential Toxicity of Polycyclic Aromatic Hydrocarbons in an Agrarian Soil," Environ. Process., vol. 7, 2020, pp. 827-844, doi: $10.1007 /$ s40710-020-00446-3.

[33] Sutherland, R. A. "Bed sediment-associated trace metals in an urban stream, Oahu, Hawaii," Environ. Geol., vol. 39, no. 6, 2000, pp. 611-627.

[34] Anifowose, A. J. and Sakugawa, H. "Determination of Daytime Flux of Nitric Oxide Radical (NO•) at an Inland Sea- Atmospheric Boundary in Japan", Journal of Aquatic Pollution and Toxicology, vol. 1, no. 2, 2017, pp. 1-6,.

[35] Odewande, A. A. and Abimbola, A. F. "Contamination indices and heavy metal concentrations in urban soil of Ibadan metropolis, southwestern Nigeria", Environ. Geochem. Health, vol. 30, no. 3, 2008, pp. 243-254, doi: 10.1007/s10653007-9112-2.

[36] Radojevic, M. and Bashkin, V. Practical environmental analysis, Royal society of chemistry, 2007.

[37] Duodu, G. O., Goonetilleke, A. and Ayoko, G. A. "Comparison of pollution indices for the assessment of heavy metal in Brisbane River sediment", Environ. Pollut., vol. 219, 2016, pp. 10771091.

[38] WHO, "Permissible limit for heavy metals in soil and plants," 1996.

[39] Yisa, J., Jacob, J. O. and Onoyima, C. C. "Assessment of toxic levels of some heavy metals in road deposited sediments in Suleja, Nigeria", Am. J. Chem., vol. 2, no. 2, 2012, pp. 34-37. 